\title{
A Survey of Human Intestinal Helminthiasis in Oguta Local Government Area of Imo State, Nigeria
}

\author{
Orji, N.M. ${ }^{1,}{ }^{*}$, Umeche, Ndu ${ }^{1}$, Dike, E.A. ${ }^{1}$ and Ezigbo, V.O. ${ }^{2}$ \\ ${ }^{1}$ Department of Biological Sciences,Chukwuemeka Odumegwu Ojukwu University,Uli,P.M.B 02 Uli, Anambra State Nigeria. \\ ${ }^{2}$ Departmentof Industrial Chemistry,Chukwuemeka Odumegwu Ojukwu University, Uli. P.M.B 02 Uli, Anambra State, Nigeria. \\ *Corresponding author's e-mail: nmorji@yahoo.com; Phone no.: +2348030921170
}

\begin{abstract}
A survey was conducted to determine the prevalence of intestinal helminthiasis in four communities in Oguta Local Government Area of Imo State, Nigeria between April 2016 and June 2017. Wet- Saline preparation and Concentration of Zinc Sulphate Floatation Technique were used in the analysis of stool samples. Of the 800 faecal samples examined, $73.9 \%$ were infected, $(25.1 \%)$ males and (48.8\%) females. Intestinal helminthes encountered were Ascaris lumbricoides (25\%), Trichuris trichura (0.8\%), Strongyloides stercoralis (5.6\%), Enterobius vermicularis $(3.1 \%)$, Taenia solium $(0.4 \%)$, Taenia saginata $(0.3 \%)$ and Hookworm (29.2\%). Ascaris lumbricoides recorded the highest prevalence with (25\%) while $T$. saginata had least with $(0.3 \%)$ respectively. Infection prevalence was highest $(40.6 \%)$ in the 7-12 years age group and least prevalence recorded in 1-6 years group. Statistically prevalence was independent on sex and age. Infection rates were significant $(\mathrm{P}<0.05)$ for the type of toilet facility, sources of water and parental occupation. It was therefore concluded that drastic measures should be taken by improving on personal and environmental hygiene, provision of essential amenities and massive education of the people on the dangers of the disease should be encouraged in order to checkmate the spread of the disease in the study area.
\end{abstract}

Original Research Article

Received: $26^{\text {th }}$ Jan., 2018

Accepted: $9^{\text {th }}$ Feb., 2018

Published: $14^{\text {th }}$ Mar., 2018

Keywords:

Human intestinal helminthes, Poor hygiene

Environmental hygiene

Oguta $L G A$

\section{INTRODUCTION}

$\mathrm{H}$ elminthes are parasitic worms which are multicellular bilaterally symmetrical elongated flat animals. Its epidemiology is greatly influenced by human behavioural and cultural practices as well as socioeconomic conditions of the people. Human intestinal helminthes constitute some of the commonest and most important infective disease agents of mankind and as such account for much morbidity and some mortality.

Intestinal parasitic infections are one of the common public health problems. It is estimated that about 3.5 billion people are affected globally and 450 million are ill as a result of these infections (WHO, 2000; WHO, 2002). It is estimated that 500 million persons are infected by Ascaris lumbricoides, Hookworm and Trichuris trichiura respectively (Udonsi and Ogan (1993); Singh (2002). The public health and socio economic consequences of Intestinal helminthiasis are of global concern particularly in developing Countries where malnutrition and other factor complicate the impact of the infection (Satyanarayana and Nema, 2005; Ogbo and Odudu, 1990). Therefore, it is the intension of this research to determine the prevalence of intestinal helminthiasis among inhabitant of four communities in Oguta Local Government Area, Imo State, Nigeria.

\section{MATERIALS AND METHODS}

\section{Study Area}

The Survey was carried out in the four Communities in Oguta Local Government Area of Imo State Nigeria (Fig. 1). Oguta LGA lies between $5^{\circ}$ and $6^{\circ}$ North of the equator of the Greenwich. It comprises of urban and rural communities with a teeming population of young people. The physical features in the area includes Oguta lake, one general hospital. Oguta has both public and private Secondary and primary Schools. 
Oguta is endowed with fertile land and the people of the area are predominantly farmers.

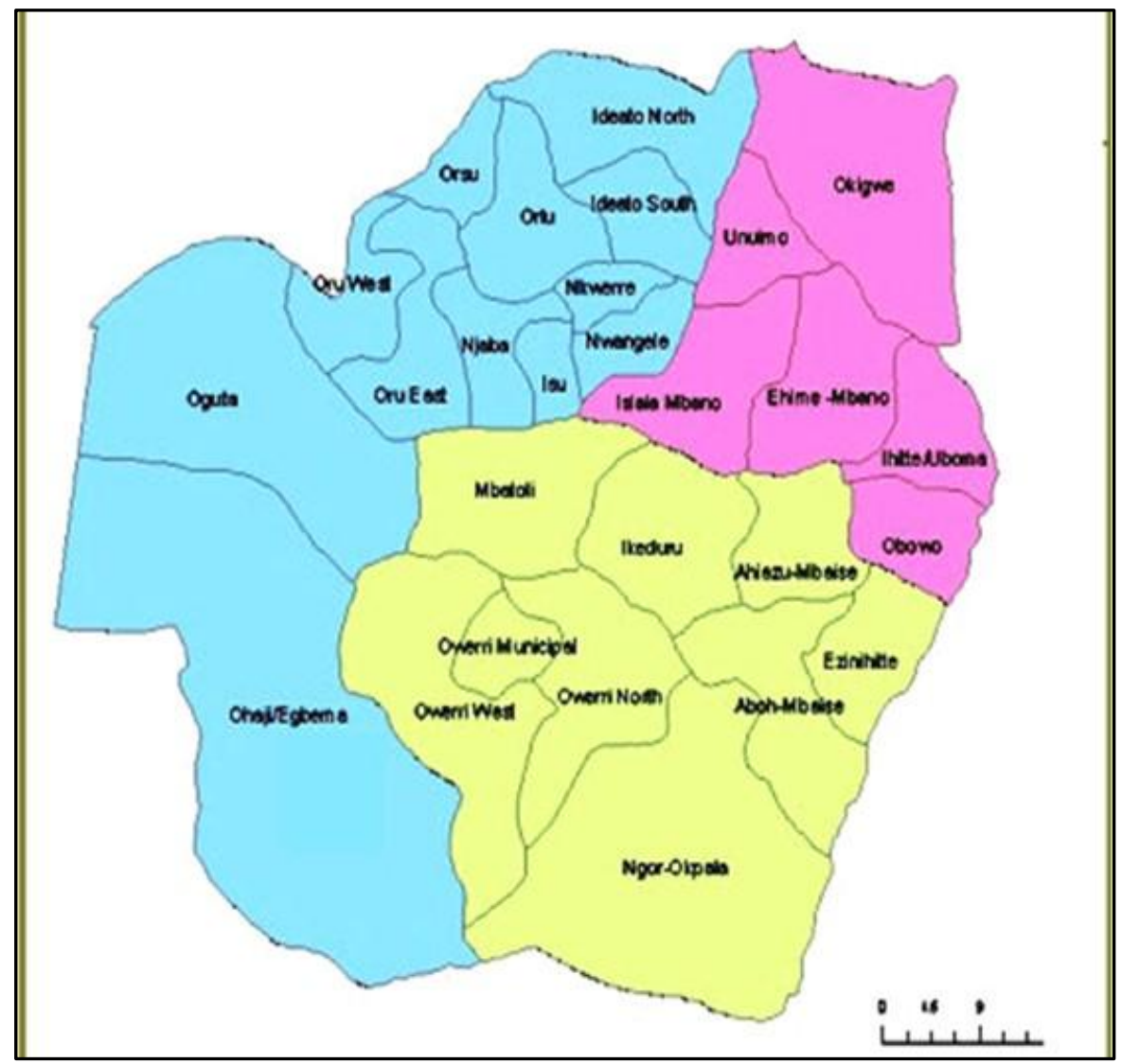

Figure 1: Map of Imo State Showing the Study Area.

\section{Sample Collection}

Faecal samples were collected from 800 consented individuals into a wide open clean containers and questionnaire were also administered to them to collect data on their age, sex the samples were taken to the laboratory for analysis.

\section{Laboratory Analysis}

About a pin head of stool was collected using collection stick and emulsified in a drop of physiological saline on a clean glass slide covered with a clean cover slip and examined under microscope low power and dry light power (Cheesbrough, 1998).

Zinc sulphate flotation method was also to concentrate the stool to check helminthes eggs and larvae that must have been missed by direct smear technique.

\section{Statistical method}

Data collected from this study were analysed using the chisquare test $\left(\mathrm{X}^{2}\right)$ to compare and test for significance

\section{RESULTS}

A $73.9 \%$ prevalence rate of human intestinal helminthiasis was recorded for the 800 persons examined in the study Area.
An overall prevalence of nematodes, cestodes and trematodes are in varying degree with Ascaris lumbricoides having the highest prevalence of $29 \%$ while Taenia saginata recorded lowest prevalence with $0.3 \%$ from one community to another infections rates ranged from $66.5 \%$ in Oguta community to $80 \%$ amongst inhabitants of Agwa community (Table 1). The calculated value of chi-square is more than the critical value. Hence a significant intestinal helminthiasis in the study Area. Table 1. Intestinal helminthiasis vary according to age. With the different age groups generally Ascaris lumbriodes showed high prevalence in all the age groups (Table 2). Children of age 7-12 years have the highest prevalence of $40.6 \%$. Children between age groups 1-6, 7-12 and 13-18 years recorded no traces of Taenia species. Prevalence of Trichuris trichuiria and Echinococcus granulosus is concentrated in ages 19years and above. Necator americanu sand Ancylostoma duodenale occur in all age groups but more prevalent in adult hood. The calculated value of chi square is greater than critical value at $\mathrm{p}<0.05$. Hence a significant difference exists in the level of prevalence among the various age groups.

The sex of the individuals at $p<0.05$ variation, did not have any influence on the prevalence of the parasite though intestinal helminthiasis was found to have occurred more in females $(48.8 \%)$ than in males $(25.1 \%)$. Calculated value of $\mathrm{X}^{2}$ is less than critical value. Hence there is no significant 
difference in the level of helminthiasis between males and females in the study area (Fig. 2).

In occupational related prevalence infection rates ranged from $61.87 \%$ in civil servants to $81.25 \%$ in farmers (Fig. 3). Pupils and students maintained a clear lead among persons infected with Ascaris lumbricoides (38.8\%) respectively. Calculated value is less than critical value $(p<0.05)$. The level of prevalence varies, a significant difference was not established among the various occupational area involved in the study.

Table 1: Overall prevalence of human intestinal helminthiasis in OgutaLGA.*

\begin{tabular}{|c|c|c|c|c|c|c|c|c|c|c|c|}
\hline 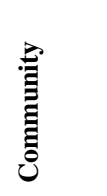 & 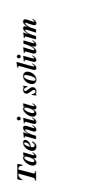 & 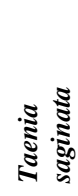 & 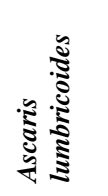 & 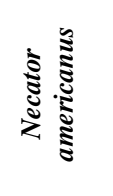 & 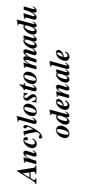 & 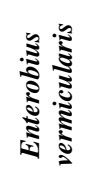 & 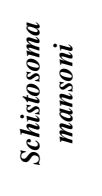 & 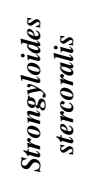 & 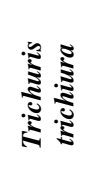 & 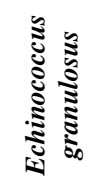 & 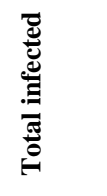 \\
\hline Agwa & $\begin{array}{l}0 \\
(0 \%)\end{array}$ & $\begin{array}{l}2 \\
(1 \%)\end{array}$ & $\begin{array}{c}65 \\
(32.5 \%)\end{array}$ & $\begin{array}{l}44 \\
(22 \%)\end{array}$ & $\begin{array}{l}28 \\
(14 \%)\end{array}$ & $\begin{array}{l}2 \\
(1 \%)\end{array}$ & $\begin{array}{l}6 \\
(3 \%)\end{array}$ & $\begin{array}{l}8 \\
(4 \%)\end{array}$ & $\begin{array}{l}3 \\
(1.5 \%)\end{array}$ & $\begin{array}{l}2 \\
(1 \%)\end{array}$ & $\begin{array}{l}\mathbf{1 6 0} \\
(80 \%)\end{array}$ \\
\hline Awa & $\begin{array}{l}0 \\
(0 \%)\end{array}$ & $\begin{array}{l}0 \\
(0 \%)\end{array}$ & $\begin{array}{l}52 \\
(26 \%)\end{array}$ & $\begin{array}{l}35 \\
(17.5 \%)\end{array}$ & $\begin{array}{l}22 \\
(11 \%)\end{array}$ & $\begin{array}{l}8 \\
(4 \%)\end{array}$ & $\begin{array}{l}13 \\
(6.5 \%)\end{array}$ & $\begin{array}{l}10 \\
(5 \%)\end{array}$ & $\begin{array}{l}1 \\
(0.5 \%)\end{array}$ & $\begin{array}{l}0 \\
(0 \%)\end{array}$ & $\begin{array}{l}142 \\
(71 \%)\end{array}$ \\
\hline Nkwesi & $\begin{array}{l}0 \\
(0 \%)\end{array}$ & $\begin{array}{l}0 \\
(0 \%)\end{array}$ & $\begin{array}{l}60 \\
(30 \%)\end{array}$ & $\begin{array}{l}22 \\
(11 \%)\end{array}$ & $\begin{array}{l}40 \\
(20 \%)\end{array}$ & $\begin{array}{l}7 \\
(3.5 \%)\end{array}$ & $\begin{array}{l}8 \\
(4 \%)\end{array}$ & $\begin{array}{l}15 \\
(7.5 \%)\end{array}$ & $\begin{array}{l}0 \\
(0 . \%)\end{array}$ & $\begin{array}{l}4 \\
(2 \%)\end{array}$ & $\begin{array}{l}156 \\
(78 \%)\end{array}$ \\
\hline Oguta & $\begin{array}{l}2 \\
(1 \%)\end{array}$ & $\begin{array}{l}0 \\
(0 \%)\end{array}$ & $\begin{array}{l}55 \\
(27.5 \%)\end{array}$ & $\begin{array}{l}24 \\
(12 \%)\end{array}$ & $\begin{array}{l}19 \\
(9.5 \%)\end{array}$ & $\begin{array}{l}8 \\
(4 \%)\end{array}$ & $\begin{array}{l}10 \\
(5 \%)\end{array}$ & $\begin{array}{l}12 \\
(6 \%)\end{array}$ & $\begin{array}{l}2 \\
(1 \%)\end{array}$ & $\begin{array}{l}1 \\
(0.5 \%)\end{array}$ & $\begin{array}{l}133 \\
(66.5 \%)\end{array}$ \\
\hline Total & $\begin{array}{l}3 \\
(0.2 \%)\end{array}$ & $\begin{array}{l}2 \\
(0.3)\end{array}$ & $\begin{array}{l}232 \\
(29 \%)\end{array}$ & $\begin{array}{l}125 \\
(15.6 \%)\end{array}$ & $\begin{array}{l}109 \\
(13.6 \%)\end{array}$ & $\begin{array}{l}25 \\
(3.1 \%)\end{array}$ & $\begin{array}{l}37 \\
(4.6 \%)\end{array}$ & $\begin{array}{l}45 \\
(5.6 \%)\end{array}$ & $\begin{array}{l}6 \\
(0.8 \%)\end{array}$ & $\begin{array}{l}7 \\
(0.9 \%)\end{array}$ & $\begin{array}{l}591 \\
(73.9 \%)\end{array}$ \\
\hline
\end{tabular}

*Total number of people examined: 800. Number examined in each community: 200.

Table 2: Age related prevalence of human intestinal helminthiasis in Oru East LGA.*

\begin{tabular}{|c|c|c|c|c|c|c|c|c|c|c|c|}
\hline 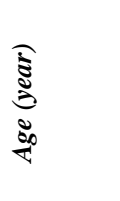 & 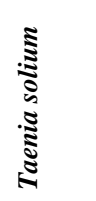 & 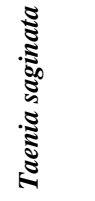 & 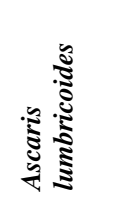 & 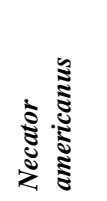 & 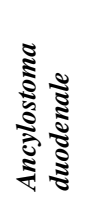 & 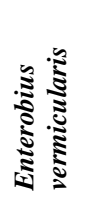 & 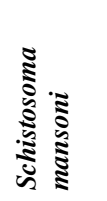 & 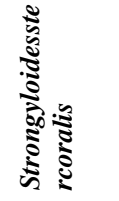 & 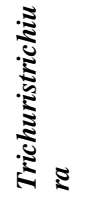 & 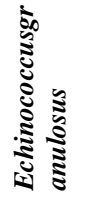 & 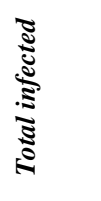 \\
\hline $1-6$ & $\begin{array}{l}0 \\
(0 \%)\end{array}$ & $\begin{array}{l}0 \\
(0 \%)\end{array}$ & $\begin{array}{l}45 \\
(28.1 \%)\end{array}$ & $\begin{array}{l}6 \\
(3.8 \%)\end{array}$ & $\begin{array}{l}3 \\
(1.9 \%)\end{array}$ & $\begin{array}{l}2 \\
(1.3 \%)\end{array}$ & $\begin{array}{l}1 \\
(0.6 \%)\end{array}$ & $\begin{array}{l}3 \\
(1.9 \%)\end{array}$ & $\begin{array}{l}0 \\
(0 \%)\end{array}$ & $\begin{array}{l}0 \\
(0 \%)\end{array}$ & $\begin{array}{l}60 \\
(37.5 \%)\end{array}$ \\
\hline $7-12$ & $\begin{array}{l}0 \\
(0 \%)\end{array}$ & $\begin{array}{l}0 \\
(0 \%)\end{array}$ & $\begin{array}{l}83 \\
(51.9 \%)\end{array}$ & $\begin{array}{l}19 \\
(11.9 \%)\end{array}$ & $\begin{array}{l}17 \\
(10.6 \%)\end{array}$ & $\begin{array}{l}7 \\
(4.4 \%)\end{array}$ & $\begin{array}{l}2 \\
(1.3 \%)\end{array}$ & $\begin{array}{l}1 \\
(0.6 \%)\end{array}$ & $\begin{array}{l}0 \\
(0 \%)\end{array}$ & $\begin{array}{l}0 \\
(0 \%)\end{array}$ & $\begin{array}{l}129 \\
(80.6 \%)\end{array}$ \\
\hline $13-18$ & $\begin{array}{l}0 \\
(0 \%)\end{array}$ & $\begin{array}{l}0 \\
(0 \%)\end{array}$ & $\begin{array}{l}64 \\
(40 \%)\end{array}$ & $\begin{array}{l}31 \\
(91.4 \%)\end{array}$ & $\begin{array}{l}24 \\
(15 \%)\end{array}$ & $\begin{array}{l}9 \\
(5.6 \%)\end{array}$ & $\begin{array}{l}10 \\
(6.3 \%)\end{array}$ & $\begin{array}{l}6 \\
(3.8 \%)\end{array}$ & $\begin{array}{l}0 \\
(0 \%)\end{array}$ & $\begin{array}{l}0 \\
(0 \%)\end{array}$ & $\begin{array}{l}144 \\
(90 \%)\end{array}$ \\
\hline $19-24$ & $\begin{array}{l}0 \\
(0 \%)\end{array}$ & $\begin{array}{l}2 \\
(0.3 \%)\end{array}$ & $\begin{array}{l}49 \\
(30.6 \%)\end{array}$ & $\begin{array}{l}30 \\
(18.8 \%)\end{array}$ & $\begin{array}{l}29 \\
(18.1 \%)\end{array}$ & $\begin{array}{l}4 \\
(2.5 \%)\end{array}$ & $\begin{array}{l}19 \\
(11.9 \%)\end{array}$ & $\begin{array}{l}18 \\
(11.3 \%)\end{array}$ & $\begin{array}{l}0 \\
(0 \%)\end{array}$ & $\begin{array}{l}0 \\
(0 \%)\end{array}$ & $\begin{array}{l}151 \\
(94.4 \%)\end{array}$ \\
\hline 25 above & $\begin{array}{l}2 \\
(1.3 \%)\end{array}$ & $\begin{array}{l}0 \\
(0 \%)\end{array}$ & $\begin{array}{l}22 \\
(13.8 \%)\end{array}$ & $\begin{array}{l}34 \\
(21.3 \%)\end{array}$ & $\begin{array}{l}28 \\
(17.5 \%)\end{array}$ & $\begin{array}{l}3 \\
(1.9 \%)\end{array}$ & $\begin{array}{l}16 \\
(10 \%)\end{array}$ & $\begin{array}{l}12 \\
(7.5 \%)\end{array}$ & $\begin{array}{l}2 \\
(1.3 \%)\end{array}$ & $\begin{array}{l}2 \\
(1.3 \%)\end{array}$ & $\begin{array}{l}121 \\
(57.6 \%)\end{array}$ \\
\hline Total & $\begin{array}{l}2 \\
(0.3 \%)\end{array}$ & $\begin{array}{l}2 \\
(0.3 \%)\end{array}$ & $\begin{array}{l}263 \\
(32.9 \%)\end{array}$ & $\begin{array}{l}120 \\
(15 \%)\end{array}$ & $\begin{array}{l}101 \\
(12.6 \%)\end{array}$ & $\begin{array}{l}25 \\
(3.1 \%)\end{array}$ & $\begin{array}{l}48 \\
(5 \%)\end{array}$ & $\begin{array}{l}40 \\
(5 \%)\end{array}$ & $\begin{array}{l}2 \\
(0.3 \%)\end{array}$ & $\begin{array}{l}2 \\
(0.3 \%)\end{array}$ & $\begin{array}{l}605 \\
(75.6 \%)\end{array}$ \\
\hline
\end{tabular}

*Total number of people examined: 800 . Number examined in each community: 160 . 


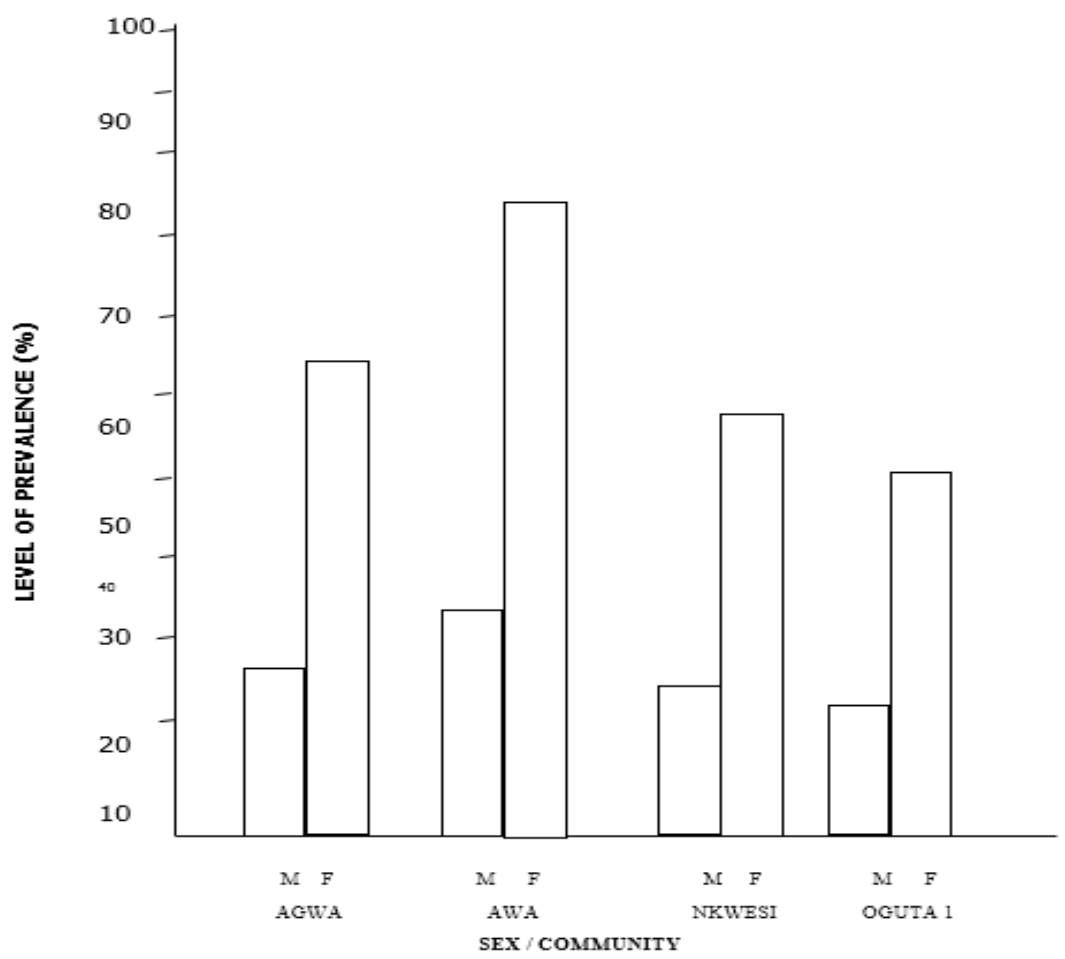

Figure 2: Sex Related Prevalence of Human Intestinal helminthiasis in Oguta Local Govt. Area.

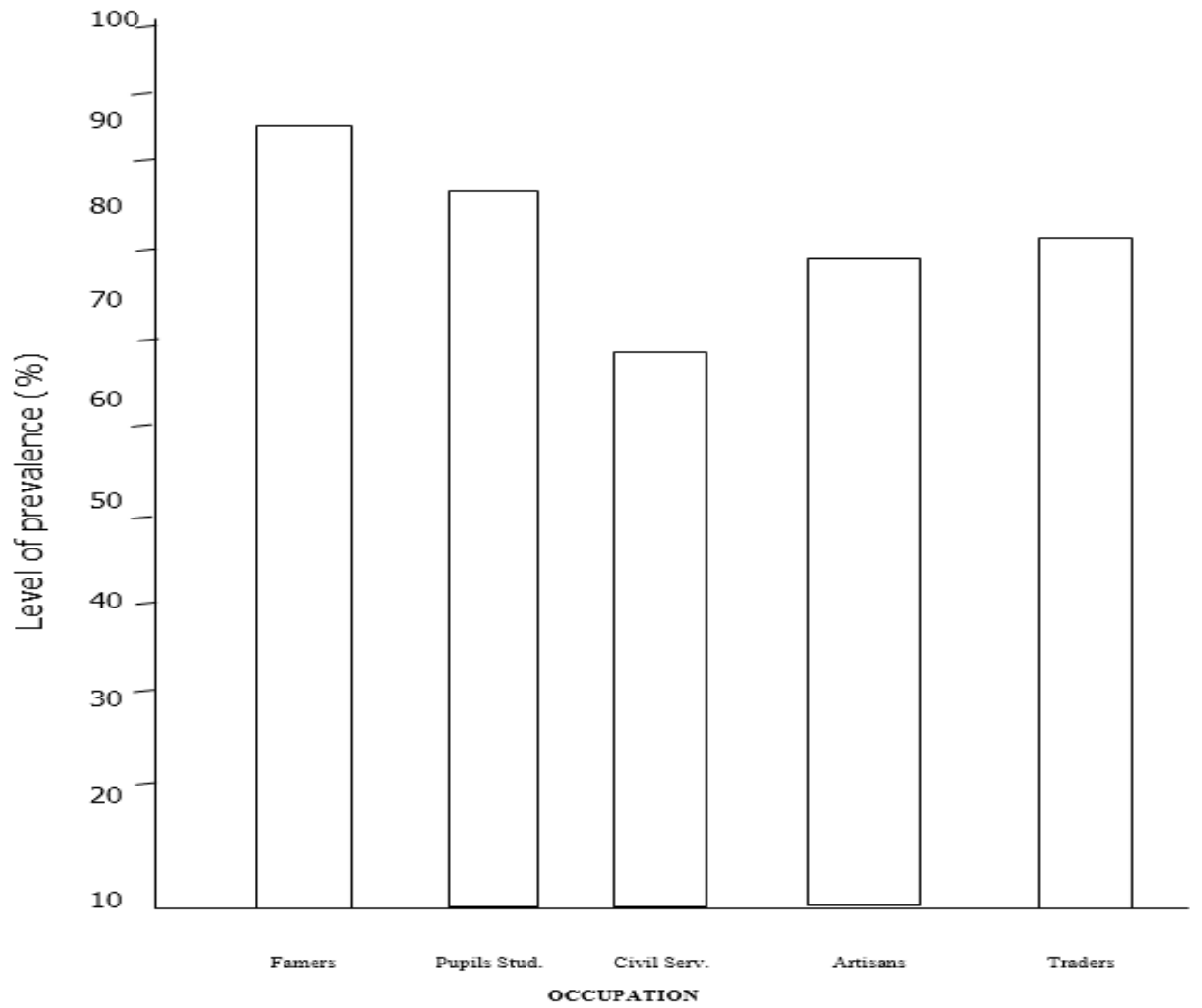

Figure 3: Occupation related prevalence of helminthiasisin Oguta LGA.

\section{DISCUSSION}

The results of the study showed that human intestinal helminthes infections are relatively high in Oguta Local Government Area of Imo state which might be due to the absence of pipe borne water in most of the villages, total dependence of inhabitants on streams and low standard of hygiene (Orji et al., 2011; Alo et al., 1993). The higher prevalence of the various helminthes encountered in the age group 7-12 years might be due to the fact that people in this age group spend more time in the water washing, fishing or playing. They are often in contact with the soil and are fond of eating indiscriminately with unwashed hands (Anderson, 1982). Epidemiological studies and prevalence of human intestinal helminthiasis have been carried out in some parts of Nigeria. Here in Imo state, most of the research works by researchers in Owerri urban were in hookworm (Necator americanus) hence the need to look for other helminthes in 
the state (Obi et al., 2010). The high prevalence raises the need for aggressive implementation of intermittent preventive treatment on the inhabitants of Oguta especially on the children of the study area, limiting further transmission of the disease. Health Education is also very necessary in the control of this disease (Dasiliva et al., 2003).

From the result, it is evident that one of the consequences of helminthiasis in the Study Area are poor personal and environmental hygiene. This findings agrees with the results from similar studies (Orji et al., 2012; Choi and Wrong, 1984).

Nigeria as a geographic entity belongs to the tropics in which the temperature is constantly favourable for the parasites to thrive and multiply rapidly. The prevalent poor sanitation conditions in the rural areas favoured the spread of faeces around the homes are of special importance in this regard of helminthes transmission. Such faeces deposited around dwelling house contain thousands of helminthes eggs, which under the hot humid climate and soft sandy worm soil of the environment develop into enormous population infections larvae around human habitations (Anderson, 1982). The absence of medical care in the rural areas helps to worsen the situation. Even where medical facilities are available, people tend to ignore them. Consequently, ignored helminthiasis undermines the health of the rural population causing retarded mental growth in children, general weakness and laziness, often accompanied by acute mental distress in adults. Generally the acute sufferer wastes away and is more susceptible to other disease causing agents in the environment. Untreated heavy infestations in the poorly nourished people are responsible for many deaths in the rural areas. Poor rural dwellers are highly vulnerable to helminthiasis, the reason must be associated with the ways of life of the people-their educational background, their economic well-being, their food and feeding habits, occupation etc. This supports the work of (Obi et al, 2010). In conclusion, food vendors should be educated on proper hygiene. Government should also organize seminars and workshop for the masses especially the food vendors. Inhabitants of Oguta especially children should be enlightened on hand hygiene practices. Finally, Government should include health education in school curriculum starting from nursery schools to tertiary schools.

\section{REFERENCES}

Alo, E.B., Anosike J.C. and Danburan J.B., (1993): “A survey of intestinal helminthes among students or post-primary institution in Adamawa State Nigeria. Applied parasitology. 34:161-167.
Anderson, R.M., (1982). The population dynamics and control of hookworm and roundworm infections. In: R.M. Anderson (Ed) population of dynamics of infectious diseases Chapman and Hall London pp 67--106.

Cheesbrough.M.1998.District Laboratory Practice in Tropical Countries (Part 1). Cambridge University Press.uk. pp. 454

Choi, T.K., and Wrong, J., (1984): Severe acute Pancreatitis caused by Parasites in the common bile duct. Journal of Tropical Medical Hygience 87; 211-214.

Desilva, N.R., Booker, S, Hotez, P. J. Monstresor, A., Engles, D., Salvioli, L., (2003). Soil Transimitted helminth infections: updating the Global Picture. Trends parasitol. 19, 547-551.

Obi, R.K., Oyibo, W.A., Akangba, C.C., Nwanebu, F.C., Orji,N.M and NdubisiU.U.(2010). Human adaptation to Parasitism. Asian J. Exp.Biol.Sci.Vol 1(2). Pp 283-287.

Ogbe, M.G., Odudu, L.A. (1990); Gastro intestinal helminthiasis in primary School in EpeL.G. Area Lagos State. Nigeria. The Nigeria. J.of parasitology 9-11 pp 95-106.

Orji, N.M., Obi, RK. and Onyemaibeya, OM.(2011). Prevalence of intestinal parasitiasis among pregnant women at the antenatal clinics in Ekwusigo Local Government Area Anambra State,South Eastern Nigeria. International Journal of Natural and Applied Sciences .vol 4(3) pp 18-24.

Orji, N.M., Okafor, J.E., Obi, R.K., Ezeigbo, E.U., and Opara, K.N. (2012). Intestinal parasite and Nutritional Status Among school children of Mmiata - Anam, Anambra West Local Government Area, Anambra State,Nigeria. Internet Journal of Parasitic Diseases Vol 5(1). 1559-4629.

Satyanarayana, S. Nema, S., (2005). Disseminated strongylodessterconalis in AIDS a report from India. India J. Pathol, Microbiology, 48:472-74.

Singh, S, (2002). Human Strongyloidiasis in AIDS eva: its zoonotic importance. J. Assoc. Physicians India, 50:425-22.

Udonsi, J.K. and Ogan, V.N. (1993). Primary Health Care interventions in the control of three intestinal nematodes infections in endemic communications of Niger Delta, Public Health, 107,53-60.

World Health Organization (2000). Intestinal parasite available at http:iiwww.who.inte/eld/intpara/burdeno/htm accessed may 2000.

World Health Organization, (2002). Prevention and control of schistosomiasis and soil transmitted helminthiasis, report of a WHO expert committee. Geneva, World Health Organization, WHO technical report series no 912 p 63.

\section{$\underline{\text { How to cite this article }}$}

Orji, N.M., Umeche, Ndu, Dike, E.A. and Ezigbo, V.O. (2018). A Survey of Human Intestinal Helminthiasis in Oguta Local Government Area of Imo State, Nigeria. Tropical Journal of Applied Natural Sciences, 2(2): 73-77. Doi: https://doi.org/10.25240/TJANS.2018.2.2.10. 